\title{
Integrated Procurement-Production Inventory Model with Two-Stage Production
}

\author{
Dana Marsetiya Utama *, Heri Mujayin Kholik, Azis Fredy Mulya \\ Jurusan Teknik Industri, Fakultas Teknik, Universitas Muhammadiyah Malang, Indonesia \\ Jl. Raya Tlogomas No.246 Malang, Jawa Timur, Indonesia \\ * Corresponding author: dana@umm.ac.id
}

\section{ARTICLE INFO}

\section{Article history}

Received May 20, 2020

Revised July 28, 2020

Accepted August 20, 2020

Available Online August 30, 2020

Keywords

integrated

Procurement-production

Inventory

Management

Dragonfly

\section{ABSTRACT}

The inventory-production system concerns the effective management of the goods flows from raw materials to finished products. The Integrated Procurement-Production (IPP) system consists of many elements that must be managed effectively. The problem will be more complex if it involves deciding on the number of delivery frequencies at the retailer level. In this case, the Integrated Procurement-Production's objective function depends on the frequency of raw material shipments, the frequency of delivery of finished products, and the production cycle time. This study aims to develop an IPP system to maximize total profit. The decision variables used are the frequency of raw material delivery, the frequency of delivery of finished products, and the production cycle time. This study proposes the Dragonfly Algorithm (DA) as an algorithm for problem-solving. Dragonfly Algorithm is used to find the best inventory decision variables. This study conducted experiments with various iteration parameters and DA population. The results showed that the greater the iteration and the population used, the greater the profit. A sensitivity analysis of decision variables is also presented in this investigation.

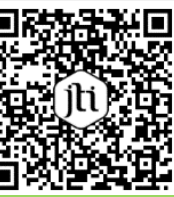

This is an open-access article under the CC-BY-SA license.

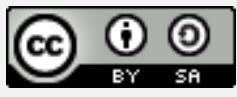

\section{Introduction}

Inventory is one of the main factors that become a problem in the production process [1]. Inventory is usually considered an asset in the company [2]. Since economic order quantity (EOQ) supply control was introduced in 1912, many researchers have developed models for solving various supply problems [3] [4] [5]. Conventionally, the economic lot size of the raw material is determined separately from the finished product. This decision leads to the resulting sub-optimization solution [6]. The demand for raw materials depends on the production plan for the finished product [7]. Because of this, Goyal [8] was the first researcher to develop the Economic Order Quantity (EOQ) formula into an Integrated Procurement-Production (IPP) system. In this IPP model, the 
procurement-production system is related to effective management, from the goods flow of raw materials to finished products distributed to customers [9].

There are several studies related to the IPP inventory model that are of concern to researchers. Several inventory models have been developed to overcome this problem. Goyal and Deshmukh [10] develop a model of the IPP system in Just In Time environment. Fauza, et al. [6] develop a procurement-production model that considers the decline in product quality. The reduction in the procurement-production inventory model is also proposed for food products [11]. In addition, Vaziri, et al. [12] conduct a study by integrating EOQ with Economic Production Quantity by considering limited warehouse capacity. Several studies have also developed integrated inventory models for singleproduct systems [8] [13] [14]. Tarhini, et al. [15] develop a single vendor-integrated production inventory model with shipping. Research with a decision of integration results optimally in supply chain system [16] [17] [18].

Most of the studies used heuristic procedures [10] [8] and Genetic Algorithm (GA) procedures [11] [12] [19] [20] [21] [22]. Several other studies have proposed the Simulated Annealing procedure [23]. Popular genetic algorithms are used to solve optimization problems. An example is Leuveano, et al. [24] utilizing a genetic algorithm in an integrated procurement-production system with a combination of a just-in-time delivery system. For the most part, researchers develop models with the objective function of minimizing total costs [21] [25] [26] [27]. In addition, many studies investigated are for single-stage production problems [10] [8]. To the author's knowledge, no previous research has examined the problem of a two-stage production IPP system model. Whereas in the IPP system, two-stage production problems are often encountered in the industry.

Based on the description above, this study aims to develop an IPP model to maximize total profit. In this study, a two-stage production IPP mathematical model is proposed. The model developed aims to provide solutions to the inventory of raw materials, goods in process, and finished products. The model is following the actual situation that occurs. This study also proposes the Dragonfly Algorithm (DA) as an algorithm for solving problems. Dragonfly Algorithm is a new meta-heuristic optimization technique to solve single, discrete, and multi-purpose problems [28]. There are no researchers who have used the Dragonfly Algorithm to solve IPP problems. Dragonfly Algorithm is used to find maximum profit based on decision variables (frequency of ordering raw materials, frequency of delivery of finished products, and production cycle times). This study's contributions are 1) providing a proposed IPP model for two-stage production; (2) proposing the DA algorithm as a solution finding procedure. This research is expected to close the gap in managing IPP inventory, especially two-stage production.

This paper's structure is presented as follows: assumptions, notations, mathematical models, algorithmic models, data collection, and experimental procedures are presented in section 2. The effect of iteration parameters and DA population on profit and the effect of changes in decision variables on profit is presented in the results and discussion of section 3. Conclusions and suggestions are presented in section 4 .

\section{Methods}

\subsection{Description, Assumption, and Notation Problems}

An illustration of the IPP two-stage production problem is presented in Fig. 1. Raw materials are processed at the $p_{1}$ production rate. From this stage, the semi-finished material (WIP) is produced. The second manufacturing stage is the production process.

Please cite this article as: Utama, D. M., Kholik, H. M., \& Mulya, A. F. (2020). Integrated Procurement-Production Inventory Model with Two-Stage Production. Jurnal Teknik Industri, 21(2), 185-199. 
The production process requests as much $d_{1}$ semi-finished material. The semi-finished material is processed at the $p_{2}$ production rate. Because it is assumed that one unit of the finished product requires one unit of half-finished material, so $d_{1}$ is equal to $p_{2}$. From the second stage, as many $d_{2}$ finished products are produced. In the two-stage manufacturing process, raw materials are sent $m$ times.

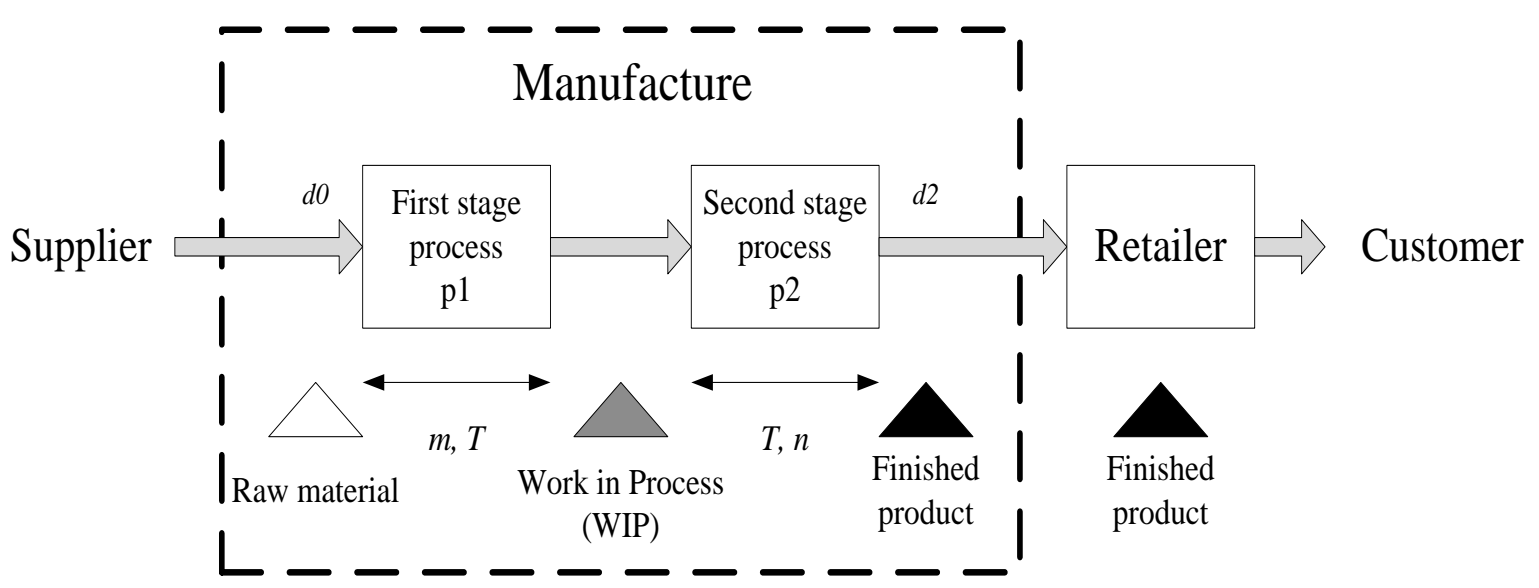

Fig. 1. Two-Stage System in Manufacture

In Fig. 2 it is explained that the factory places orders for raw materials by the $\left(q_{0}\right)$ number of orders and the $q_{0} / d_{0}$ order cycle. The production rate of the first process is $p_{1}$. Since it is assumed that one unit of semi-finished material requires one unit of raw material, so $d_{0}$ is equal to $p_{1}$. Therefore, the ordering cycle is the same as $q_{0} / p_{1}$. Furthermore, the inventory of semi-finished materials, where the raw materials are processed into WIP materials during $T p_{1}\left(T P_{1}=Q_{1} / p_{1}\right.$, in which $Q_{1}$ is the quantity with the production rate $\left.\left(p_{1}\right)\right)$. During $T P_{2}$, the number of WIP will run out continuously. $I_{\max }$ on the WIP system is the same as $\left(p_{1}-p_{2)}\right) * Q_{1} / p_{1}$. In the finished product inventory at the factory, WIP is processed at $\left(p_{2}\right)$ production rate within production limits $\left(T P_{2}\right)$ to meet demand during production (T), or $Q_{2}=d_{2} * T$ that $T P_{2}$ is equal to $d_{2} * T / p_{2}$. The finished product is shipped in batches (by $q_{2}$ transfer batch size) of (n) times during production. Therefore, the finished product order cycle in retailer is equal to $q_{2} / d_{2}$

The Integrated Procurement Production (IPP) model aims to provide a policy for supplying raw materials, in-process products, and finished products. Fauza, et al. [29]. The development of the IPP system model needs to determine the assumptions and notations used. The assumptions of this supply model are:

1. The production rate and the level of demand are constant and deterministic where $p_{1}>p_{2}>d_{2}$

2. Shortage and backorder are not allowed

3. Ignoring waiting time transportation

4. There is no loss of quality

5. One finished product requires one WIP unit, and one WIP unit requires one raw material 

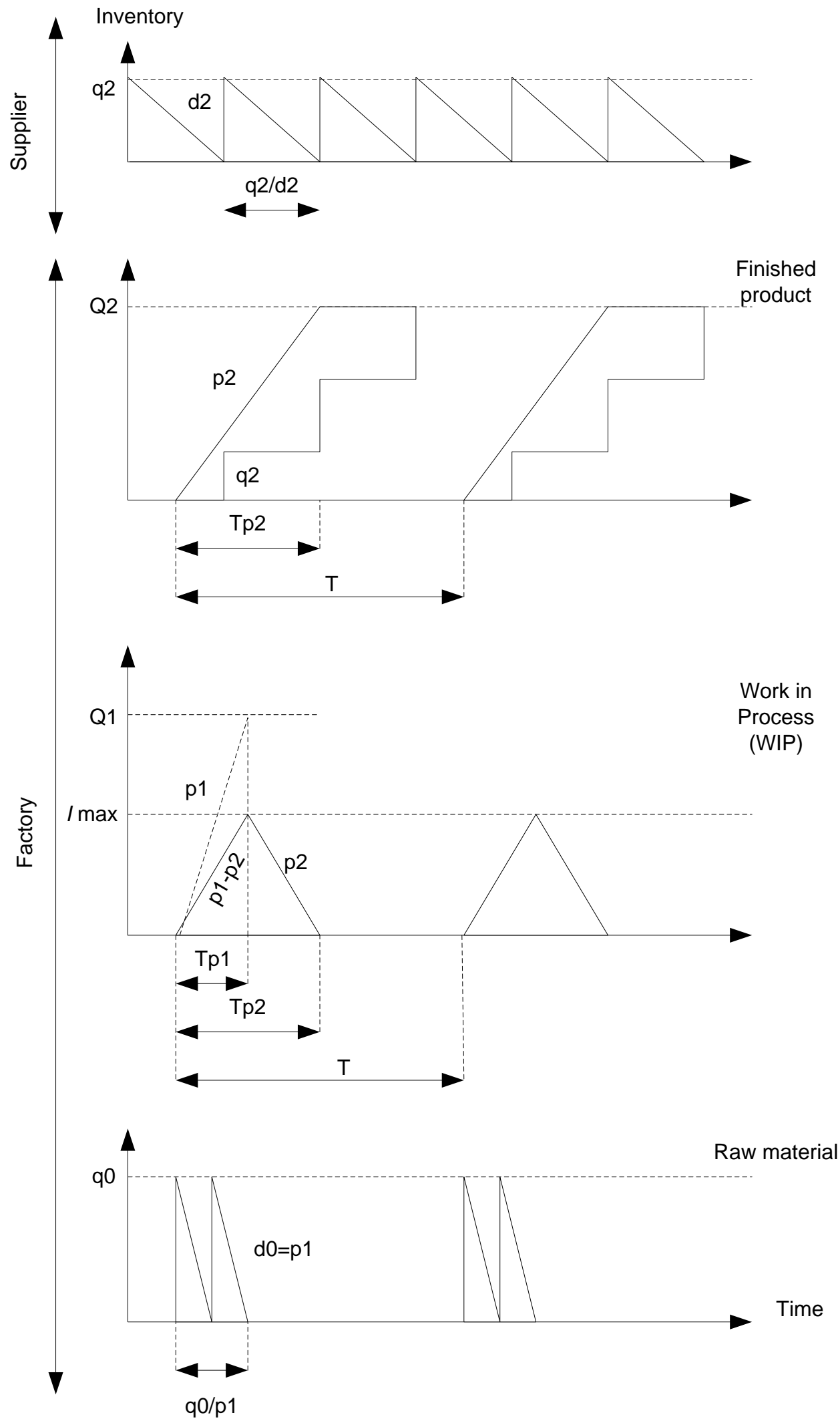

Fig. 2. Integrated Procurement-production Inventory System

Please cite this article as: Utama, D. M., Kholik, H. M., \& Mulya, A. F. (2020). Integrated Procurement-Production Inventory Model with Two-Stage Production. Jurnal Teknik Industri, 21(2), 185-199. 
The notation used in this problem is

$p_{1} \quad$ : production rate of semi-finished products production (units/month)

$p_{2} \quad$ : production rate of finished products production (unit/month)

$d_{0} \quad$ : the number of raw material demands (units/month)

$d_{1} \quad$ : the number of demands for semi-finished products (units/month) in which

$$
d_{1}: p_{2}
$$

$d_{2} \quad:$ the number of demands for finished products (units/month)

$c_{\text {sale }} \quad$ : the cost of finished product purchase from retailer to the company (IDR/order)

$c_{0} \quad$ : the cost of raw material purchase (IDR/order)

$c_{1} \quad$ : the cost of semi-finished product processing (IDR/ unit)

$c_{2} \quad$ : the cost of finished products processing (IDR/unit)

$A_{0} \quad$ : the cost of shipping transportation of raw material (IDR/time unit)

$A_{1} \quad$ : the cost of shipping transportation finished goods (IDR/time unit)

$S_{1} \quad$ : the cost of setup of semi-finished products processing (IDR/time unit)

$S_{2} \quad$ : the cost of setup of finished products processing (IDR/time unit)

$H_{0} \quad$ : the cost of raw materials storing (IDR/time unit)

$H_{1} \quad$ : the cost of semi-finished products storing (IDR/time unit)

$\mathrm{H}_{2}$ : the cost of finished products storing (IDR/time unit)

$\mathrm{I}_{0} \quad$ : the average of raw material inventory (unit)

$I_{1} \quad$ : the average of semi-finished products inventory (units)

$I_{2} \quad$ : the average of finished products inventory (unit)

$R_{\text {ret }} \quad$ : the total retail revenue/income (IDR/time unit)

$P_{\text {max }}$ : product price at maximum (IDR)

$T C_{0} \quad$ : the total cost of raw material inventory system (IDR/time unit)

$T C_{1}$ : the total cost of half-finished products inventory system (IDR/time unit)

$T C_{2}$ : the total cost of finished products inventory system (IDR/time unit)

JTC : the total cost of the integrated inventory system (IDR/time unit)

JTR : the total revenue/income of integrated inventory system (IDR/time unit)

JTP : the total profit of the integrated inventory system (IDR/time unit)

$\mathrm{m} \quad$ : frequency of raw materials demands (times/demand)

$\mathrm{T} \quad$ : time during the production cycle (one time)

$\mathrm{n} \quad$ : frequency of finished products shipping (times/time unit)

\subsection{Model Development}

This section describes the development of an IPP system model to maximize profit. The development of a mathematical model of the problem can be formulated as follows:

$$
\begin{aligned}
& I_{0}=\frac{d_{0}{ }^{2} T}{2 m p_{1}} \\
& I_{1}=\frac{d_{2}\left(p_{1}-p_{2}\right) d_{2} T}{2 p_{1} p_{2}} \\
& I_{2}=\frac{d_{2} T}{2 n}\left(\frac{d_{2}}{p_{2}}(2-n)+(n-1)\right)+\frac{d_{2} T}{2 n} \\
& \mathrm{TC}_{0}(\mathrm{~m}, \mathrm{~T})=c_{0} p_{1}+A_{0} \frac{m}{T}+H_{0} \frac{d_{0}{ }^{2} T}{2 m p_{1}}
\end{aligned}
$$




$$
\begin{aligned}
& T C_{1}(T)=c_{1} d_{1}+\frac{S_{1}}{T}+H_{1} \frac{d_{2}\left(p_{1}-p_{2}\right) d_{2} T}{2 p_{1} p_{2}} \\
& \mathrm{TC}_{2}(\mathrm{~T}, \mathrm{n})=\mathrm{c}_{2} \mathrm{~d}_{2}+\frac{\mathrm{S}_{2}}{\mathrm{~T}}+H_{2}\left(\left(\frac{d_{2} T}{2 n}\left(\frac{d_{2}}{p_{2}}(2-n)+(n-1)\right)\right)+\frac{d_{2} T}{2 n}\right)+A_{1} \frac{n}{T} \\
& \operatorname{JTR}(T, n)=c_{\text {sales }} d_{2}+\sum_{i=1}^{n} R_{\text {ret }_{i}}(T, n)
\end{aligned}
$$

Equation (1) - (3) performs an average inventory starting from $\left(I_{0}\right)$ raw materials, $\left(I_{1}\right)$ in-process products, and $\left(I_{2}\right)$ finished products. Equation (4) calculates the cost system of total raw material inventory, which consists of raw material purchase costs, transportation costs of raw material delivery, raw material storage costs, and the cost of decreasing raw material quality. Equation (5) is the calculation of the total cost of inprocess products. The cost of finished product inventory is done by adding up WIP costs, installation costs for finished processing products, storage costs for finished products, transportation costs of finished product delivery, and finished product purchases as in equation (6). Meanwhile, equation (7) is the calculation of the total income in an integrated inventory system.

From equations (1) - (7), the total profit of the integrated inventory system can be calculated by using the following mathematical model:

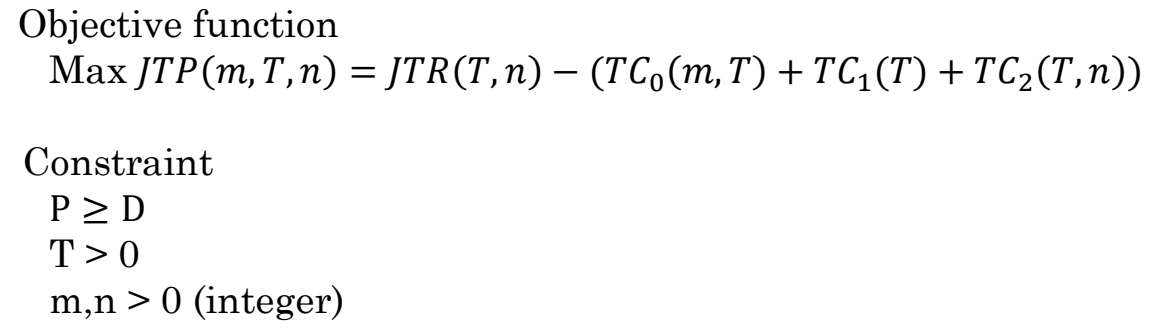

Equation (8) is the objective function in the model development of the IPP system. This objective function aims to determine the maximum total profit. Equation (9) - (11) is a delimiting function.

\subsection{Dragonfly Algorithm}

This study proposes the Dragonfly Algorithm method to help solve problems. Dragonfly Algorithm is an algorithm that is inspired by the behavior of dragonflies. Dragonflies are luxurious insects. There are nearly 3000 different species of these insects worldwide [28] [30] [31] [32]. The main inspiration of the DA algorithm comes from clustered behavior in static and dynamic manners. These two clustering behaviors are very similar to the two main phases of optimization using meta-heuristics: exploration and exploitation [30]. The notations needed in Dragonfly Algorithm include:
$\mathrm{Si} \quad$ : the avoidance of static collisions from one individual to another
$\mathrm{Ai} \quad$ : indicates the suitability of an individual's velocity for another in the environment
$\mathrm{Ci}$ : the tendency of the individual towards the center of the environment mass
$\mathrm{Fi}$ : attraction to food sources
Gi : disturbance of enemy emersion 
$\Delta X_{t+1}:$ the direction of the dragonfly movement

$X_{t+1} \quad$ : calculation of $\mathrm{Xt}$, and $\Delta X_{t+1}$

$\operatorname{Levy}(x)$ : the dragonfly flying direction around the search room using a random path

Dragonflies form sub-swarm and fly over different areas in static swarms, which is the main objective of the exploration phase. However, dragonflies fly in larger groups and together in one direction, advantageous in the exploitation phase. These two phases are mathematically implemented in the following sections:

$$
\mathrm{Si}=-\sum_{j=1}^{N} X-X_{j}
$$

Wherein $\mathrm{X}$ is the individual's current position, $\mathrm{Xj}$ shows the position of the individual neighbor $\mathrm{j}$-th, and $\mathrm{N}$ is the number of individual neighbors.

$$
A_{i}=\frac{\sum_{j=1}^{N} V_{j}}{N}
$$

Wherein $\mathrm{Xj}$ indicates the velocity of the individual neighbor $\mathrm{j}$-th.

$$
C_{i}=\frac{\sum_{j=1}^{N} X_{j}}{N}-X
$$

Wherein $\mathrm{X}$ is the individual's current position, $\mathrm{N}$ is the number of environments, and $\mathrm{Xj}$ represents the individual's position to the $\mathrm{j}$ neighbor.

$$
\mathrm{F}_{\mathrm{i}}=\mathrm{X}^{+}-\mathrm{X}
$$

Wherein $\mathrm{X}$ is the individual's current position, and $\mathrm{X}^{+}$indicates the position of the food source.

$$
\mathrm{G}_{\mathrm{i}}=\mathrm{X}^{-}+\mathrm{X}
$$
position.

Wherein $\mathrm{X}$ is the current position of the individual, and $\mathrm{X}$ - indicates the enemy

$$
\Delta X_{t+1}=\left(s S_{i}+a A_{i}+c C_{i}+f F_{i}+e E_{i}\right)+w \Delta X_{t}
$$

Wherein s denotes the weight of the separation, Si shows the individual separation to $\mathrm{i}$-th, $\mathrm{a}$ is the alignment weight, $\mathrm{A}$ is the alignment of the individual to $\mathrm{i}$-th, $\mathrm{c}$ represents the weight of the cohesion, $\mathrm{Ci}$ is the cohesion of the individual to $\mathrm{i}$-th, $\mathrm{f}$ is the food factor, $\mathrm{Fi}$ is the individual's food source to $\mathrm{i}$-th, $\mathrm{g}$ is the enemy factor, $\mathrm{G}_{\mathrm{i}}$ is the individual's enemy position to $\mathrm{i}$-th, $\mathrm{w}$ is the inertia weight, and $\mathrm{t}$ is the iteration counter.

$$
X_{t+1}=X_{t}+\Delta X_{t+1}
$$

Wherein $\mathrm{t}$ is the current iteration.

$$
X_{t+1}=X_{t}+\operatorname{Levy}(d) \times X_{t}
$$


Where $t$ is the current iteration, and $d$ is the dimension of the position vector.

$$
\operatorname{Levy}(x)=0.01 \times \frac{r 1 \times \sigma}{|r 2|^{\frac{1}{\beta}}}
$$

Where $r 1, r 2$ are two random numbers in $[0,1], \beta$ is constant (equal to 1.5$)$ in this case.

$\sigma=\left(\frac{\Gamma(1+\beta) x \sin \left(\frac{\pi \beta}{2}\right)}{\Gamma\left(\frac{1+\beta)}{2}\right) \times \beta \times 2\left(\frac{\beta-1}{2}\right)}\right)^{1 / \beta}$

Wherein. $\Gamma(x)=(x-1)$ !

The following is the pseudo-code used to maximize the JTP of Fig. 3

Initialize the dragonflies population Xi $(\mathrm{i}=1,2, \ldots, \mathrm{n})$

Initialize step vectors $\Delta \mathrm{Xi}(\mathrm{i}=1,2, \ldots, \mathrm{n})$

while the end condition is not satisfied

Calculate the objective values of all dragonflies

Update the food source and enemy

Update w, s, a, c, f, and g

Calculate S, A, C, F, and G using Eqs. (12) to (16)

Update neighbouring radius

If a dragonfly has at least one neighbouring dragonfly

Update velocity vector using Eq. (19)

Update position vector using Eq. (20)

else

Update position vector using Eq. (20)

end if

Check and correct the new positions based on the boundaries of variables

end while

return $\mathrm{Xa}$

Fig. 3. Pseudo-code Dragonfly Algorithm

In this two-stage IPP problem, the number of dimensions used is 3 . This number is based on the decision variables $\mathrm{m}, \mathrm{n}$, and $\mathrm{T}$. $\mathrm{m}$ and $\mathrm{n}$ variables are discrete variables. While the $\mathrm{T}$ decision variable is a continuous value. This study proposes a continuous conversion of numbers to discrete, as illustrated in Fig. 4. For example, the conversion provision is that the value of $m$ and $n$ is an integer with a range of 1 to 100 . At the same time, $\mathrm{T}$ is a continuous number with a range of 0 to 1 . The $m$ and $n$ variables are rounded up if a decimal value is $0 \geq 0.5$. Otherwise, it will be rounded down. 


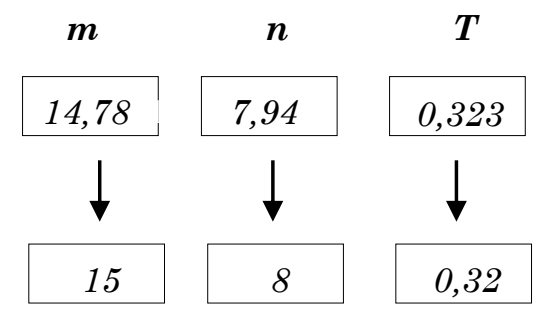

Fig. 4. Conversion of Decision Variable Value

\subsection{Experimental Data and Procedures}

In this section, data collection and experimental procedures are described. A case study was conducted in a manufacturing company in Indonesia. There are several data parameters used in the study. The required data parameters consist of $p_{1}, p_{2}, d_{0}$, $d_{1}, d_{2}, c_{\text {sale }}, c_{0}, c_{1}, c_{2}, A_{0}, A_{1}, S_{1}, S_{2}, H_{0}, H_{1}, H_{2}$, and $P_{\text {max }}$. In Table 1 , the collection of data parameters used is presented.

Table 1. Data Collection

\begin{tabular}{ccc} 
Parameter & Value & Unit \\
\hline$p_{1}$ & 6 & ton/month \\
$p_{2}$ & 5.7 & ton/month \\
\hline$d_{0}$ & 6 & ton/month \\
$d_{1}$ & 5.7 & ton/month \\
$d_{2}$ & 5.4 & ton/month \\
\hline$c_{\text {sale }}$ & $185,000,000$ & IDR/ton \\
\hline$c_{0}$ & $70,000,000$ & IDR/ton \\
\hline$c_{1}$ & $5,500,000$ & IDR/ton \\
\hline$c_{2}$ & $7,000,000$ & IDR/ton \\
\hline$A_{0}$ & 750,000 & IDR/order \\
\hline$A_{1}$ & 600,000 & IDR/delivery \\
\hline$S_{1}$ & 130,000 & IDR/month \\
\hline$S_{2}$ & 250,000 & IDR/month \\
\hline$H_{0}$ & 400,000 & IDR/ton \\
\hline$H_{1}$ & 550,000 & IDR/ton \\
$H_{2}$ & 650,000 & IDR/ton \\
\hline$P_{\text {max }}$ & $197,000,000$ & IDR/ton \\
\hline
\end{tabular}


The objective function of the IPP is to maximize the total system profit (Equation 8). This experiment uses a population and iteration number of 10,50 , and 100 . The dimension meant here is the decision variables used in the IPP. There are three dimensions used, namely the frequency of raw materials demands $(\mathrm{m})$, the frequency of the finished product delivery (n), and the time of production cycle (T). The upper and lower limits are used as the value limits for the decision variables. The optimal solution is also compared to the GA algorithm used, namely crossover rate of 0.7 and migration of 0.2 for every 20 generations, referring to the research of Nagib, et al. [33].

This research uses demand, production, and costs which can be seen in 2 . The setting of the Dragonfly Algorithm (DA) parameter value consists of;

Population : : 100

Iteration $\quad: 100$

The lower limit : : $\left[\begin{array}{lll}0 & 0 & 0\end{array}\right]$

The upper limit : : [10 10 10 1 [

Experiments were carried out using the MATLAB R2014a software. After knowing the value of the decision variable that produces the best profit, an analysis of $\mathrm{m}, \mathrm{n}$, and T's values is carried out on the resulting profit. Analysis of the decision variables $m$ and $n$ was tried with ten different values. As for the $T$ value, a sensitivity analysis was also carried out with a value range of 1 to 0.1844 . The sensitivity analysis procedure is as follows: When one of the decision variables is changed, the other decision variables are set to the optimal decision variable value. This sensitivity analysis is used to determine the effect of the decision variable value on profit.

\section{Results and Discussion}

\subsection{Effect of Iteration and Population on Profit}

The Dragonfly Algorithm (DA) method is used to process the data obtained in Table 2 using the MATLAB R2014a software. The results of the software calculation experiments are presented in Table 2.

Table 2. Software Calculation Results

\begin{tabular}{cccccc}
\hline \multirow{2}{*}{ Iteration } & Population & $\begin{array}{c}\text { Objective } \\
\text { Function }\end{array}$ & \multicolumn{3}{c}{ Decision Variables } \\
\cline { 2 - 6 } & Profit (IDR) & $\mathrm{m}$ & $\mathrm{n}$ & $\mathrm{T}$ \\
\hline \multirow{3}{*}{10} & 10 & $566,810,000$ & 1 & 1 & 0.2615 \\
\cline { 2 - 6 } & 50 & $569,340,000$ & 1 & 2 & 1 \\
\hline \multirow{3}{*}{50} & 100 & $569,380,000$ & 1 & 2 & 0.9142 \\
\cline { 2 - 6 } & 10 & $568,640,000$ & 3 & 1 & 1 \\
\hline \multirow{3}{*}{100} & 50 & $569,380,000$ & 1 & 2 & 0.8843 \\
\cline { 2 - 6 } & 100 & $569,380,000$ & 1 & 2 & 0.8844 \\
\hline & 10 & $569,160,000$ & 2 & 3 & 1 \\
\hline & 50 & $569,380,000$ & 1 & 2 & 0.8844 \\
\hline
\end{tabular}

Please cite this article as: Utama, D. M., Kholik, H. M., \& Mulya, A. F. (2020). Integrated Procurement-Production Inventory Model with Two-Stage Production. Jurnal Teknik Industri, 21(2), 185-199. 
The experimental results in Table 2 shows that the profit increases when the population used is getting bigger. Conversely, when the population is used smaller, the profit generated will also be smaller. The biggest profit obtained was 569,380,000 IDR on 10, 50, and 100 iterations with a population of 100 . Table 3 also shows decision (m), (n), and $(\mathrm{T})$ variables. The decision variable in 50 iterations 100 population, 100 population 50 iterations, and 100 iterations and 100 population show the same results because the profit obtained is maximum.

The total profit calculation results using the Dragonfly Algorithm are equal to $569,380,000$ IDR in the integrated inventory system. By using the company's existing solution, the company's profit is 560,740,000 IDR. Based on the results of the proposed solution, the efficiency is $1.52 \%$. It shows that the total profit with Dragonfly Algorithm is more efficient.

\subsection{Effects of Changes in $\mathrm{m}, \mathrm{n}$, and $\mathrm{T}$ on Total Costs}

The effect of changes in $\mathrm{m}, \mathrm{n}$, and $\mathrm{T}$ on total costs is presented in Table 3 to Table 5. Sensitivity analysis is used to determine the effect of changes in $(\mathrm{m}),(\mathrm{n}),(\mathrm{T})$ decision variables on $\mathrm{TP}, \mathrm{JTR}, \mathrm{TC}_{0}, \mathrm{TC}_{1}, \mathrm{TC}_{2}$.

Table 3. The effect of changes $m$ on total costs (IDR)

\begin{tabular}{cccccc}
\hline $\mathrm{m}$ & $\mathrm{TP}$ & $\mathrm{JTR}$ & $\mathrm{TC}_{0}$ & $\mathrm{TC}_{1}$ & $\mathrm{TC}_{2}$ \\
\hline 1 & $569,380,000$ & $1,063,800,000$ & $421,910,000$ & $31,559,000$ & $40,951,000$ \\
2 & $569,060,000$ & $1,063,800,000$ & $422,230,000$ & $31,559,000$ & $40,951,000$ \\
3 & $568,390,000$ & $1,063,800,000$ & $422,900,000$ & $31,559,000$ & $40,951,000$ \\
4 & $567,630,000$ & $1,063,800,000$ & $423,660,000$ & $31,559,000$ & $40,951,000$ \\
5 & $566,840,000$ & $1,063,800,000$ & $424,450,000$ & $31,559,000$ & $40,951,000$ \\
6 & $566,020,000$ & $1,063,800,000$ & $425,270,000$ & $31,559,000$ & $40,951,000$ \\
7 & $565,200,000$ & $1,063,800,000$ & $426,090,000$ & $31,559,000$ & $40,951,000$ \\
8 & $564,370,000$ & $1,063,800,000$ & $426,920,000$ & $31,559,000$ & $40,951,000$ \\
9 & $563,540,000$ & $1,063,800,000$ & $427,750,000$ & $31,559,000$ & $40,951,000$ \\
10 & $562,700,000$ & $1,063,800,000$ & $428,590,000$ & $31,559,000$ & $40,951,000$ \\
\hline
\end{tabular}

From the results of the analysis in Table 3 , the selected $\mathrm{m}$ variable is 1 . When $\mathrm{m}$ is increased, the total profit (TP) will decrease, JTR is constant, $\mathrm{TC}_{0}$ increases, $\mathrm{TC}_{1}$ and $\mathrm{TC}_{2}$ are constant. The $\mathrm{m}$ variable value affects the cost of TC0. This result is in accordance with the research of Fauza, et al. [19]

From the results of the analysis in Table 4, the selected $\mathrm{n}$ variable is 2 . When $\mathrm{n}$ is increased, the total profit (TP) will decrease, JTR, $\mathrm{TC}_{0}$, and $\mathrm{TC}_{1}$ remain constant, and $\mathrm{TC}_{2}$ will increase. These results indicate that the $\mathrm{n}$ variable value affects $\mathrm{TC}_{2}$ costs. This result is in accordance with the research findings of Fauza, et al. [19]. From the analysis results in Table 5, the optimal $\mathrm{T}$ variable is 0.8844 . When $\mathrm{T}$ is lowered and increased from the optimal value of $\mathrm{T}$, the total TP profit decreases. 
Table 4. The effect of changes $\mathrm{n}$ on total costs (IDR)

\begin{tabular}{cccccc}
\hline $\mathrm{n}$ & $\mathrm{TP}$ & $\mathrm{JTR}$ & $\mathrm{TC}_{0}$ & $\mathrm{TC}_{1}$ & $\mathrm{TC}_{2}$ \\
\hline 1 & $568,550,000$ & $1,063,800,000$ & $421,910,000$ & $31,559,000$ & $41,784,000$ \\
2 & $569,380,000$ & $1,063,800,000$ & $421,910,000$ & $31,559,000$ & $40,951,000$ \\
3 & $569,210,000$ & $1,063,800,000$ & $421,910,000$ & $31,559,000$ & $41,125,000$ \\
4 & $568,780,000$ & $1,063,800,000$ & $421,910,000$ & $31,559,000$ & $41,552,000$ \\
5 & $568,250,000$ & $1,063,800,000$ & $421,910,000$ & $31,559,000$ & $42,079,000$ \\
6 & $567,670,000$ & $1,063,800,000$ & $421,910,000$ & $31,559,000$ & $42,657,000$ \\
7 & $567,070,000$ & $1,063,800,000$ & $421,910,000$ & $31,559,000$ & $43,263,000$ \\
8 & $566,440,000$ & $1,063,800,000$ & $421,910,000$ & $31,559,000$ & $43,888,000$ \\
9 & $565,810,000$ & $1,063,800,000$ & $421,910,000$ & $31,559,000$ & $44,524,000$ \\
10 & $565,160,000$ & $1,063,800,000$ & $421,910,000$ & $31,559,000$ & $45,169,000$ \\
\hline
\end{tabular}

Table 5. The effect of changes $\mathrm{T}$ on total costs (IDR)

\begin{tabular}{cccccc}
\hline $\mathrm{T}$ & $\mathrm{TP}$ & $\mathrm{JTR}$ & $\mathrm{TC}_{0}$ & $\mathrm{TC}_{1}$ & $\mathrm{TC}_{2}$ \\
\hline 1 & $569,340,000$ & $1,063,800,000$ & $421,950,000$ & $31,550,000$ & $40,959,000$ \\
0.9844 & $569,350,000$ & $1,063,800,000$ & $421,940,000$ & $31,551,000$ & $40,955,000$ \\
0.8844 & $569,380,000$ & $1,063,800,000$ & $421,910,000$ & $31,559,000$ & $40,951,000$ \\
0.7844 & $569,340,000$ & $1,063,800,000$ & $421,900,000$ & $31,571,000$ & $40,989,000$ \\
0.6844 & $569,210,000$ & $1,063,800,000$ & $421,920,000$ & $31,588,000$ & $41,088,000$ \\
0.5844 & $568,920,000$ & $1,063,800,000$ & $421,980,000$ & $31,614,000$ & $41,280,000$ \\
0.4844 & $568,400,000$ & $1,063,800,000$ & $422,130,000$ & $31,652,000$ & $41,621,000$ \\
0.3844 & $567,440,000$ & $1,063,800,000$ & $422,410,000$ & $31,715,000$ & $42,229,000$ \\
0.2844 & $565,610,000$ & $1,063,800,000$ & $422,980,000$ & $31,827,000$ & $43,384,000$ \\
0.1844 & $561,470,000$ & $1,063,800,000$ & $424,290,000$ & $32,068,000$ & $45,978,000$ \\
\hline
\end{tabular}

\section{Conclusion}

This study proposes a two-stage production of the IPP model to maximize profit. This study also proposes DA as a procedure to solve problems. The research results on the effect of DA parameters on profit show that the greater the iteration and population used, the more maximum the results will be obtained. The sensitivity analysis shows that the $\mathrm{m}, \mathrm{n}$, and $\mathrm{T}$ variables influence total profit. Some of the limitations of this study are the demand that is assumed to be constant and deterministic. In addition, backorders and shortages are not allowed. For further research, the stochastic characteristics of demand need to be examined in this study. The model needs to consider backorders and shortages.

\section{References}

[1] S. Ziukov, "A literature review on models of inventory management under uncertainty," Business Systems \& Economics, vol. 5, pp. 26-35 2016. https://doi.org/10.13165/VSE-15-5-1-03. 
[2] S. K. Goyal and Y. P. Gupta, "Integrated inventory models: The buyer-vendor coordination," European Journal of Operational Research, vol. 41, pp. 261-269, 1989. https://doi.org/10.1016/0377-2217(89)90247-6.

[3] S. K. D. B. Maulana, D. M. Utama, M. S. Asrofi, I. S. Ningrum, N. Alba, H. A. Ahfa, et al., "The Capacitated Sustainable EOQ Models: Models Considering Tax Emissions," Jurnal Teknik Industri, vol. 21, pp. 12-21, 2019. https://doi.org/10.22219/JTIUMM.Vol21.No1.12-21.

[4] D. M. Utama, "Model Penentuan Lot Pemesanan Dengan Mempertimbangkan Unit Diskon dan Batasan Kapasitas Gudang dengan Program Dinamis," Jurnal $\begin{array}{llllll}\text { Teknik Industri, } & \text { vol. } & \text { 18, } & \text { pp. }\end{array}$ https://doi.org/10.22219/JTIUMM.Vol18.No1.94-102.

[5] D. M. Utama, D. S. Widodo, M. F. Ibrahim, K. Hidayat, and S. K. Dewi, "The Sustainable Economic Order Quantity Model: A Model Consider Transportation, Warehouse, Emission Carbon Costs, and Capacity Limits," Journal of Physics: Conference Series, vol. 1569, p. 022095, 2020. https://doi.org/10.1088/17426596/1569/2/022095.

[6] G. Fauza, Y. Amer, and S.-H. Lee, Model of an integrated procurement-production system for food products incorporating quality loss during storage time vol. 1: IACSIT-Internal Association of Computer Science, 2013. https://doi.org/10.7763/IJMMM.2013.V1.4.

[7] D. M. Utama, D. P. Wardani, S. T. Halifah, and D. C. Pradikta, "Model Economic Production Quantity dengan Rework Process dan Batasan Gudang," Jurnal Sistem dan Manajemen Industri, vol. 3, pp. 43-49, 2019. https://doi.org/10.30656/jsmi.v3i1.1017.

[8] S. K. Goyal, "An Integrated Inventory Model for a Single Product System," Journal of the Operational Research Society, vol. 28, pp. 539-545, 1977. https://doi.org/10.1057/jors.1977.103.

[9] S. K. Goyal and S. G. Deshmukh, "Integrated procurement-production systems: A review," European Journal of Operational Research, vol. 62, pp. 1-10, 1992. https://doi.org/10.1016/0377-2217(92)90172-6.

[10] S. K. Goyal and S. G. Deshmukh, "Integrated procurement- production system in a just-in-time environment-modelling and analysis," Production Planning \& Control, vol. 8, pp. 31-36, 1997. https://doi.org/10.1080/095372897235532.

[11] G. Fauza, H. Prasetyo, and B. S. Amanto, "An integrated production-inventory model for food products adopting a general raw material procurement policy," in IOP Conference Series: Materials Science and Engineering, 2018, p. 012013. https://doi.org/10.1088/1757-899x/352/1/012013.

[12] S. Vaziri, A. Zaretalab, M. Esmaeili, and S. T. A. Niaki, "An integrated production and procurement design for a multi-period multi-product manufacturing system with machine assignment and warehouse constraint," Applied Soft Computing, vol. 70, pp. 238-262, 2018. https://doi.org/10.1016/j.asoc.2018.05.037.

[13] S. H. Kim and J. Chandra, "An integrated inventory model for a single product and its raw materials," International Journal of Production Research, vol. 25, pp. 627634, 1987. https://doi.org/10.1080/00207548708919866.

[14] S. K. Goyal, "Improving the solution of a finite horizon inventory problem under certainty," International Journal of Production Research, vol. 15, pp. 173-178, 1977. https://doi.org/10.1080/00207547708943115. 
[15] H. Tarhini, M. Karam, and M. Y. Jaber, "An integrated single-vendor multi-buyer production inventory model with transshipments between buyers," International Journal of Production Economics, vol. 225, p. 107568, 2020. https://doi.org/10.1016/j.ijpe.2019.107568.

[16] M. A. Hoque and S. K. Goyal, "An optimal policy for a single-vendor single-buyer integrated production-inventory system with capacity constraint of the transport equipment," International Journal of Production Economics, vol. 65, pp. 305-315, 2000. https://doi.org/10.1016/S0925-5273(99)00082-1.

[17] C. Yan, A. Banerjee, and L. Yang, "An integrated production-distribution model for a deteriorating inventory item," International Journal of Production Economics, vol. 133, pp. 228-232, 2011. https://doi.org/10.1016/j.ijpe.2010.04.025.

[18] X. Liu, W. Wang, and R. Peng, "An integrated production, inventory and preventive maintenance model for a multi-product production system," Reliability Engineering \& System Safety, vol. 137, pp. 76-86, 2015. https://doi.org/10.1016/j.ress.2015.01.002.

[19] G. Fauza, Y. Amer, S.-H. Lee, and H. Prasetyo, "An integrated single-vendor multibuyer production-inventory policy for food products incorporating quality degradation," International Journal of Production Economics, vol. 182, pp. 409-417, 2016. https://doi.org/10.1016/j.ijpe.2016.09.009.

[20] G. Fauza, Y. Amer, S. H. Lee, and H. Prasetyo, "An inventory model of productioninventory policy for food products considering quality loss in raw materials," in 2015 IEEE International Conference on Industrial Engineering and Engineering Management (IEEM), 2015, pp. 910-914. https://doi.org/10.1109/IEEM.2015.7385780.

[21] M. Pourakbar, R. Z. Farahani, and N. Asgari, "A joint economic lot-size model for an integrated supply network using genetic algorithm," Applied Mathematics and $\begin{array}{lllll}\text { Computation, } & \text { vol. } & 189, & \end{array}$ https://doi.org/10.1016/j.amc.2006.11.116.

[22] G. Fauza, H. Prasetyo, and B. S. Amanto, "Development of an integrated production-inventory model for food products considering exponential perceived value loss," IOP Conference Series: Materials Science and Engineering, vol. 403, p. 012050, 2018. https://doi.org/10.1088/1757-899x/403/1/012050.

[23] K. Sarrafha, S. H. A. Rahmati, S. T. A. Niaki, and A. Zaretalab, "A bi-objective integrated procurement, production, and distribution problem of a multi-echelon supply chain network design: A new tuned MOEA," Computers \& Operations Research, vol. 54, pp. 35-51, 2015. https://doi.org/10.1016/j.cor.2014.08.010.

[24] A. C. Leuveano, F. A. B. Jafar, and M. R. B. Muhamad, "Development of genetic algorithm on multi-vendor integrated procurement-production system under shared transportation and just-in-time delivery system," in 2012 2nd International Conference on Uncertainty Reasoning and Knowledge Engineering, 2012, pp. 78-81. https://doi.org/10.1109/URKE.2012.6319589.

[25] S. K. Goyal, S. G. Deshmukh, and A. S. Babu, "A Model for Integrated Procurement-Production Systems," Journal of the Operational Research Society, vol. 41, pp. 1029-1035, 1990. https://doi.org/10.1057/jors.1990.161.

[26] F. Raafat, "A production-inventory model for decaying raw materials and a decaying single finished product system," International Journal of Systems Science, vol. 16, pp. 1039-1044, 1985. https://doi.org/10.1080/00207728508926731.

Please cite this article as: Utama, D. M., Kholik, H. M., \& Mulya, A. F. (2020). Integrated Procurement-Production
Inventory Model with Two-Stage Production. Jurnal Teknik Industri, 21(2), 185-199. https://doi.org/10.22219/JTIUMM.Vol21.No2.185-199 
[27] P.-C. Yang and H.-M. Wee, "Economic ordering policy of deteriorated item for vendor and buyer: An integrated approach," Production Planning \& Control, vol. 11, pp. 474-480, 2000. https://doi.org/10.1080/09537280050051979.

[28] S. Mirjalili, "Dragonfly algorithm: a new meta-heuristic optimization technique for solving single-objective, discrete, and multi-objective problems," Neural Computing and Applications, vol. 27, pp. 1053-1073, 2016. https://doi.org/10.1007/s00521-0151920-1.

[29] G. Fauza, H. Prasetyo, N. K. Dania, and B. S. Amanto, "Development of food inventory model in an integrated vendor-buyer system: Case study in food industry," AIP Conference Proceedings, vol. 1977, p. 020053, 2018. https://doi.org/10.1063/1.5042909.

[30] S. Mirjalili and A. Lewis, "S-shaped versus V-shaped transfer functions for binary Particle Swarm Optimization," Swarm and Evolutionary Computation, vol. 9, pp. 1-14, 2013. https://doi.org/10.1016/j.swevo.2012.09.002.

[31] C. Shilaja and K. Ravi, "Optimal Power Flow Using Hybrid DA-APSO Algorithm in Renewable Energy Resources," Energy Procedia, vol. 117, pp. 1085-1092, 2017. https://doi.org/10.1016/j.egypro.2017.05.232.

[32] M. A. Salam, H. M. Zawbaa, E. Emary, K. K. A. Ghany, and B. Parv, "A hybrid dragonfly algorithm with extreme learning machine for prediction," in 2016 International Symposium on INnovations in Intelligent SysTems and Applications (INISTA), 2016, pp. 1-6. https://doi.org/10.1109/INISTA.2016.7571839.

[33] A. N. M. Nagib, A. N. Adnan, A. Ismail, N. H. A. Halim, and N. S. Khusaini, "The Role of Hybrid Make-to-Stock (MTS) - Make-to-Order (MTO) and Economic Order Quantity (EOQ) Inventory Control Models in Food and Beverage Processing Industry," in IOP Conference Series: Materials Science and Engineering, 2016, p. 012003. https://doi.org/10.1088/1757-899x/160/1/012003. 